\title{
Produktivitas Pengarang Menggunakan Hukum Lotka Dengan Teknik Complete Count Pada Jurnal Kedokteran YARSI Tahun 2009-2018
}

\author{
Danang Dwijo Kangko $^{1 *}$; Rahmadhani ${ }^{1}$; Elfitri Kurnia Erza ${ }^{1}$ \\ ${ }^{1}$ Universitas YARSI \\ *Korespondensi: danang.dwijo@yarsi.ac.id
}

\begin{abstract}
Researchers research to develop science. Research results are published as a form of scientific communication. One type of scientific publication is a journal article. YARSI Medical Journal is a peer-reviewed journal in the field of medicine and health that is open to the public owned by YARSI University. The author's productivity patterns in the YARSI Medical Journal so far are unknown. Author productivity is the number of papers produced by the author on a particular subject and published in scientific journals in a certain period. This study aims to (1) Determine the author's productivity patterns using Lotka's Law with complete count techniques in YARSI Medical Journal 2009-2018; (2) Testing the suitability of the frequency of Lotka's Law with the author's frequency distribution using the complete count technique in YARSI Medical Journal 2009-2018. The research method used in this study is a quantitative method with bibliometric analysis. Data collection uses documentation method. The results of this study include (1) the pattern of author productivity with an exponent value (n) 2.874110535 and the constant $(C) 0.820080499$ meaning that the author contributing to one article is $82.00 \%$ of the total number of authors, it can be said that the YARSI Medical Journal Author Productivity Pattern 2009- 2018 is low or less productive. (2) Based on the K-S test the maximum deviation is 0 and the critical value is 0.0829206. Dmax is smaller than the critical value, so HO is accepted. That is, the Author Productivity Pattern uses the Complete Count Technique in YARSI Medical Journal 2009-2018 following Lotka's Law.
\end{abstract}

Keywords: Author's productivity; Lotka's Law; YARSI Medical Journal.

\begin{abstract}
Abstrak
Peneliti melakukan sebuah penelitian untuk mengembangkan ilmu pengetahuan. Hasil penelitian suatu subjek tertentu dipublikasikan sebagai bentuk komunikasi ilmiah. Salah satu jenis publikasi ilmiah tersebut adalah artikel jurnal. Jurnal Kedokteran YARSI (YARSI Medical Journal) merupakan jurnal peer-review di bidang ilmu kedokteran dan kesehatan yang bersifat terbuka untuk umum yang dimiliki oleh Universitas YARSI. Pola produktivitas pengarang pada Jurnal Kedokteran YARSI sejauh ini belum diketahui. Produktivitas pengarang adalah jumlah karya tulis yang dihasilkan oleh seorang pengarang dalam subjek tertentu dan diterbitkan pada jurnal ilmiah dalam kurun waktu tertentu.Penelitian ini bertujuan untuk (1) Mengetahui pola produktivitas pengarang menggunakan Hukum Lotka dengan teknik complete count pada Jurnal Kedokteran YARSI tahun 2009-2018; (2) Menguji kesesuaian frekuensi Hukum Lotka dengan distribusi frekuensi pengarang menggunakan teknik complete count pada Jurnal Kedokteran YARSI tahun 2009-2018. Metode penelitian yang digunakan pada penelitian ini adalah metode kuantitatif dengan analisis bibliometrik. Pengumpulan data menggunakan cara dokumentasi. Hasil penelitian; (1) pola produktivitas pengarang dengan nilai eksponen (n) 2.874110535 dan tetapan (C) 0.820080499 artinya pengarang yang berkontribusi untuk satu artikel adalah $82.00 \%$ dari total jumlah pengarang, dapat dikatakan Pola Produktivitas Pengarang Jurnal Kedokteran YARSI tahun 2009-2018 rendah atau kurang produktif (2) Berdasarkan uji K-S nilai deviasi maksimum adalah 0 dan nilai kritis 0.0829206. Dmaks lebih kecil dari nilai kritis, sehingga H0 diterima. Artinya, Pola Produktivitas Pengarang menggunakan Teknik Complete Count pada Jurnal Kedokteran YARSI Tahun 2009-2018 sesuai dengan Hukum Lotka.
\end{abstract}

Kata Kunci: Produktivitas Pengarang; Hukum Lotka; Jurnal Kedokteran YARSI.

\section{PENDAHULUAN}

Perkembangan ilmu pengetahuan tidak terlepas dari peran peneliti yang menekuni suatu bidang ilmu tertentu dalam menghasilkan suatu temuan. Hasil yang ditekuni oleh peneliti tersebut terciptalah suatu sumber informasi yang ilmiah, salah satunya yaitu jurnal. Artikel jurnal merupakan salah satu produk perkembangan ilmu perpustakaan. Lasa Hs (2017, p.46) menuturkan jurnal penelitian merupakan publikasi ilmiah yang menyajikan artikel hasil penelitian primer dan dimaksudkan sebagai media komunikasi antar penulis, antar-ahli, dan antar ilmuan tingkat nasional maupun internasional. Hasil penelitian-penelitian tersebut kemudian dipublikasikan agar bermanfaat bagi bidang ilmu tersebut maupun penelitan selanjutnya. 
Menurut Lotka (1926) dalam Wahyudi (2015, p. 4) produktivitas penulis adalah banyaknya karya tulis yang dihasilkan oleh seseorang secara individual dalam subjek tertentu dan diterbitkan pada jurnal-jurnal ilmiah dalam subjek bersangkutan dalam kurun waktu tertentu. Menurut Tsay (2004) produktifitas didefisinisikan sebagai jumlah artikel yang dipublikasikan peneliti dalam kurun waktu tertentu. Bibliometrika merupakan sebuah metode perhitungan yang menggunakan matematika dan statistik untuk mengkaji suatu informasi terekam. Menurut Endang (2012, p.7) dalam melakukan penelitian bibliometrika mengacu pada tiga teori sebagai hukum dasar salah satunya yaitu Hukum Lotka tahun 1926. Menurut Tupan (2016, p.220) kajian bibliometrik dalam ilmu informasi merupakan kajian yang dapat mengungkapkan pola pemanfaatan dokumen, perkembangan literatur atau sumber informasi dalam suatu bidang subyek.

Jurnal Kedokteran YARSI atau YARSI Medical Journal merupakan jurnal peer-review bersifat terbuka untuk umum yang dimiliki oleh Universitas YARSI. Jurnal ini fokus pada bidang ilmu kedokteran dan kesehatan. Saat ini, Jurnal Kedokteran YARSI memiliki score S6 yaitu terakreditasi peringkat 6 (enam) dengan nilai akreditasi $30 \leq \mathrm{n}<40$ oleh portal SINTA DIKTI. Pada tahun 2012 Nurningsih melakukan penelitian tentang produktivitas dosen tetap Fakultas Kedokteran Universitas YARSI pada Jurnal Kedokteran YARSI tahun 1993-2008 dengan Hukum Lotka. Penelitian tersebut menunjukan kesesuaian dengan Hukum Lotka artinya tidak terdapat perbedaan yang signifikan antara hasil pengamatan distribusi produktivitas penulis. Penelitian ini merupakan penelitian lanjutan dengan mangambil seluruh pengarang yang terdapat dalam Jurnal Kedokteran YARSI (tidak terbatas pada dosen tetap saja) selama periode tahun 2009 hingga 2018. Penelitian ini memiliki tujuan 1) Mengetahui Pola Produktivitas Pengarang menggunakan Hukum Lotka dengan Teknik complete count pada Jurnal Kedokteran YARSI tahun 2009-2018; 2) Menguji kesesuaian frekuensi Hukum Lotka dengan distribusi frekuensi pengarang menggunakan teknik complete count pada Jurnal Kedokteran YARSI tahun 2009-2018.

\section{METODE PENELITIAN}

Penelitian ini menggunakan metode kuantitatif dengan analisis bibliometrik untuk menguji Hukum Lotka pada produktivitas pengarang Jurnal Kedokteran YARSI. Menurut Wulan (2014, p.19) salah satu metode yang dapat digunakan untuk membahas produktivitas penulis adalah bibliometrika. Bibliometrika adalah salah satu metode panelitian dalam bidang ilmu perpustakaan dan informasi yang menggunakan analisis kuantitatif dan statistik dalam penyelesainnya. Penelitian ini memiliki 2 hipotesis: Pertama $H_{0}=$ Mengetahui Pola Produktivitas Pengarang Menggunakan Teknik Complete Count pada Jurnal Kedokteran YARSI Tahun 20092018 sesuai dengan Hukum Lotka. Kedua $H_{1}=$ Mengetahui Pola Produktivitas Pengarang Menggunakan Teknik Complete Count pada Jurnal Kedokteran YARSI Tahun 2009-2018 tidak sesuai dengan Hukum Lotka. Teknik complete count yaitu teknik menghitung seluruh pengarang yang ada pada Jurnal Kedokteran YARSI. Objek kajian meliputi artikel pada Jurnal tersebut. Subjek kajian dalam penelitian ini adalah penulis artikel yang muat dalam Jurnal Kedokteran YARSI. Menurut Riduwan (2014, p.54) populasi merupakan objek atau subjek yang berada ada suatu wilayah dan memenuhi syarat-syarat tertentu berkaitan dengan masalah penelitian. Populasi dalam penelitin ini adalah Jurnal Kedokteran YARSI.

Pengumpulan data dalam penelitian ini menggunakan cara dokumentasi. Menurut Martono (2016, p.43) metode dokumentasi merupakan sebuah metode pengumpulan data yang dilakukan dengan mengumpulkan berbagai dokumen yang berkaitan dengan masalah penelitian. Dokumentasi dilakukan dengan cara mengumpulkan variabel yang dibutuhkan dari setiap artikel jurnal pada Jurnal Kedokteran YARSI. Data yang diperoleh kemudian diolah menggunakan Microsoft Excel 2010 dengan tujuan memperoleh data awal dan memudahkan dalam 
pendistribusian data serta tampilan dalam format tabel selanjutnya. Data yang diambil adalah artikel pada Jurnal Kedokteran YARSI dalam rentang tahun 2009-2018 yang diakses pada situs resmi http://academicjournal.yarsi.ac.id/. Hasil analisis awal yang dilakukan terdapat 143 artikel jurnal dengan 360 pengarang pada Jurnal Kedokteran YARSI tahun 2009-2018 (lihat Tabel 1).

Tabel 1 Jumlah artikel dan pengarang Jurnal Kedokteran YARSI Tahun 2009 - 2018

\begin{tabular}{ccc} 
Tahun & Jumlah Artikel & Jumlah Pengarang \\
\hline 2009 & 26 & 66 \\
2010 & 16 & 37 \\
2011 & 0 & 0 \\
2012 & 18 & 47 \\
2013 & 6 & 16 \\
2014 & 6 & 11 \\
2015 & 18 & 49 \\
2016 & 17 & 30 \\
2017 & 18 & 53 \\
2018 & 18 & 51 \\
Jumlah & 143 & 360 \\
\hline
\end{tabular}

Penelitian ini terdiri dari lima tahapan. Alur tahapan penelitian ini adalah studi literatur, pengumpulan data, pengolahan data, analisis data, dan penulisan hasil (Lihat Gambar 1).

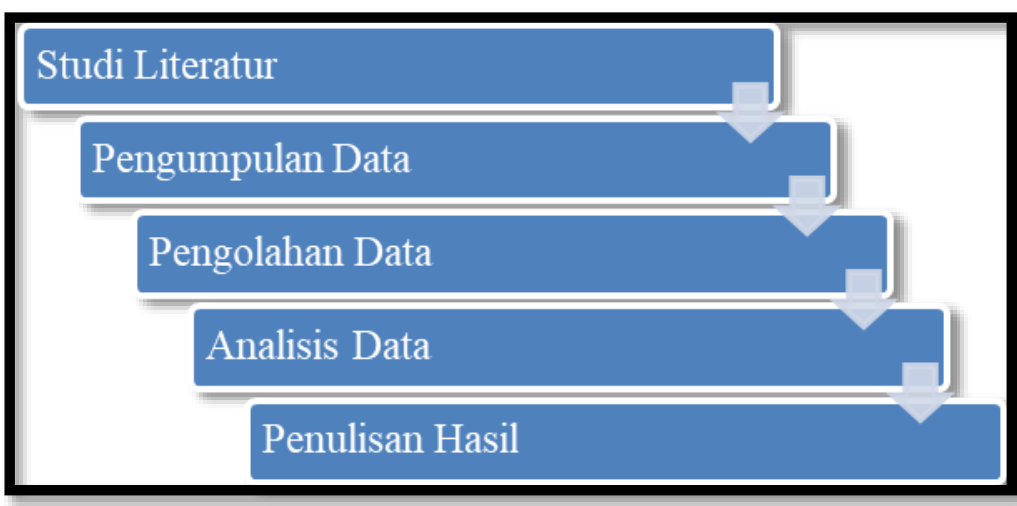

Gambar 1

Alur tahapan penelitian

\section{HASIL DAN PEMBAHASAN}

\section{Deskripsi Data}

Jurnal Kedokteran YARSI artikel ilmiah bidang kedokteran yang ditulis oleh dosen Fakultas Kedokteran Universitas YARSI dan pihak di luar Universitas YARSI. Jurnal Kedokteran YARSI terbit 3 kali dalam satu tahun (terbit per 4 bulan) dimulai dari nomor 1 pada Januari, nomor 2 pada Mei, dan nomor 3 pada September. Jurnal Kedokteran YARSI pada tahun 2009-2018 memiliki 143 artikel jurnal dan 360 pengarang dari 3 negara (lihat Gambar 2). 


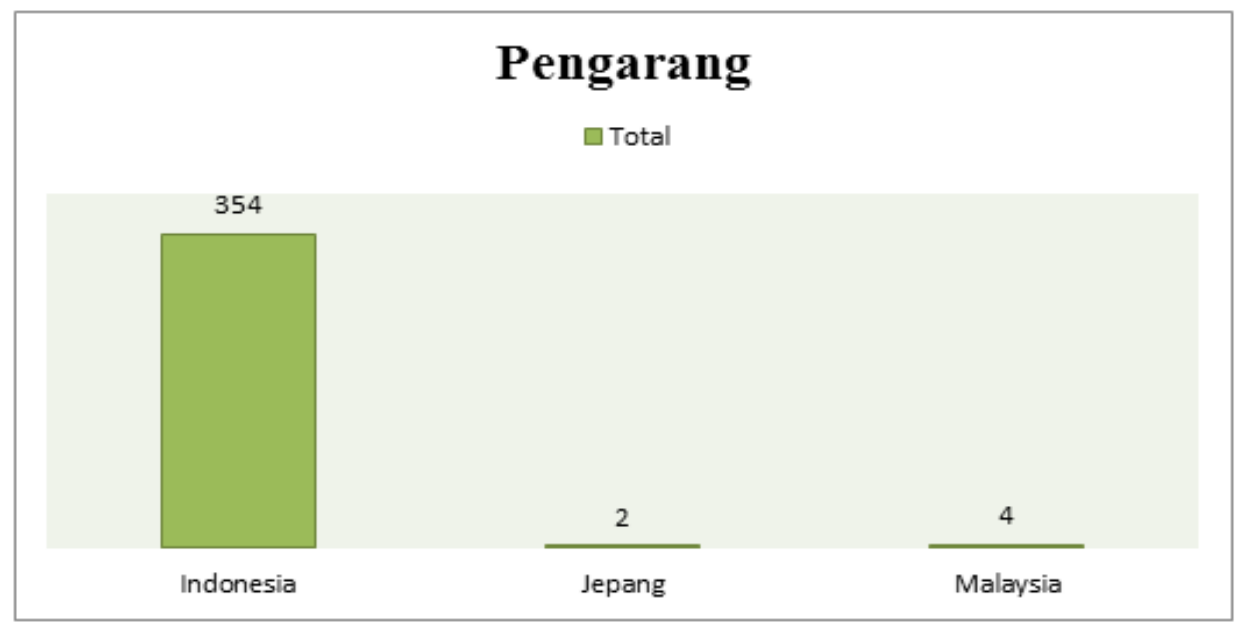

Gambar 2

Jumlah pengarangpada Jurnal Kedokteran YARSI tahun 2009-2018 berdasarkan negara.

Gambar 2 menunjukkan bahwa pengarang dalam Jurnal Kedokteran YARSI yang berasal dari Indonesia mendominasi dengan jumlah 354 orang pengarang. Berikutnya, ada pengarang yang berasal dari Malaysia berjumlah 4 orang. Terakhir, ada pengarang yang berasal dari Jepang sebanyak dua orang dalam Jurnal Kedokteran YARSI pada tahun 20092018.

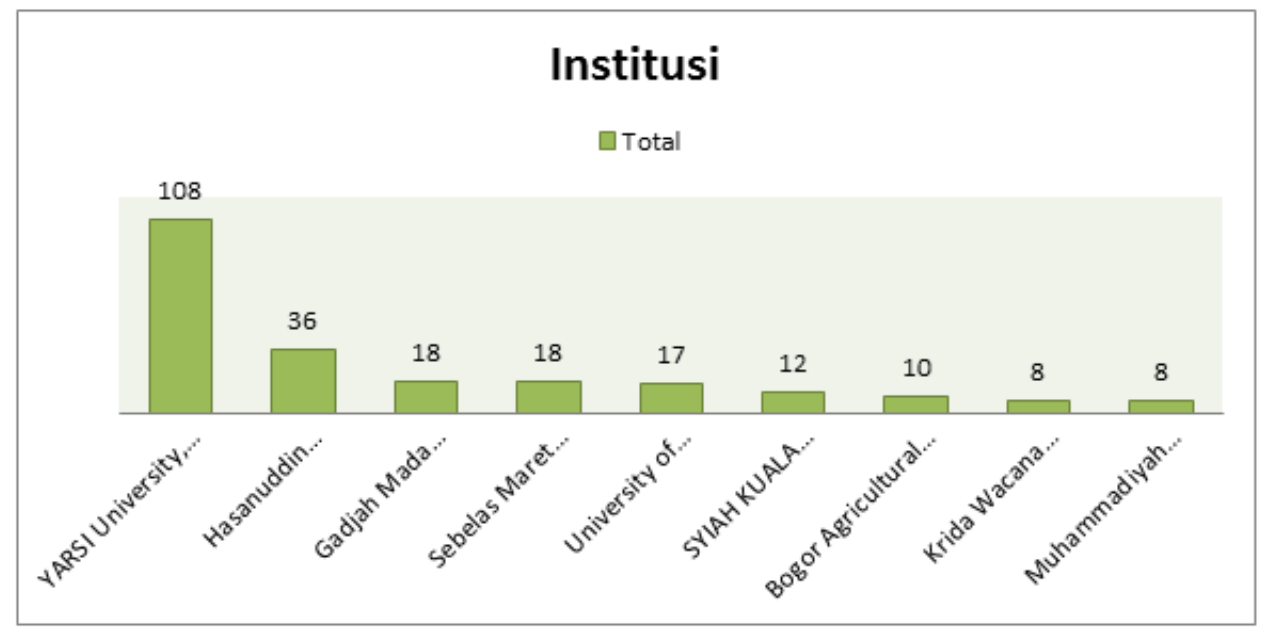

Gambar 3

Jumlah pengarang pada Jurnal Kedokteran YARSI tahun 2009-2018 berdasarkan institusi

Gambar 3 diuraikan jumlah pengarang pada Jurnal Kedokteran YARSI pada tahun 2009-2018 berdasarkan institusi asal pengarang. Berdasarkan Gambar 3 diketahui bahwa pengarang terbanyak berasal dari Universitas YARSI sebanyak 108 orang pengarang. Pengarang terbanyak kedua berasal dari Universitas Hasanuddin Makassar sebanyak 36 orang pengarang. Pengarang terbanyak ketiga berasal dari Universitas Gajah Mada dan Universitas Sebelas Maret masing-masing 18 orang pengarang.

Tabel 2

Jumlah pengarang pada Jurnal Kedokteran YARSI tahun 2009-2018 berdasarkan gender

\begin{tabular}{ccc}
\hline Gender & Jumlah & Persentase \\
\hline Laki-Laki & 155 & $43,1 \%$ \\
Perempuan & 205 & $56,9 \%$ \\
Total & 360 & $100 \%$ \\
\hline
\end{tabular}


Tabel 2 menunjukkan jumlah pengarang pada Jurnal Kedokteran YARSI periode tahun 2009-2018 berdasarkan gender. Tabel 2 menunjukkan bahwa pengarang pada Jurnal Kedokteran YARSI periode tahun 2009-2018 lebih didominasi oleh perempuan. Pengarang perempuan pada Jurnal Kedokteran YARSI periode tahun 2009-2018 ada sebanyak 205 pengarang atau $56,9 \%$. Pengarang laki-laki pada Jurnal Kedokteran YARSI periode tahun 2009-2018 ada sebanyak 155 pengarang atau 43,1\%.

\section{Analisis Data}

Terbitan Jurnal Kedokteran YARSI tahun 2009 menghasilkan 26 artikel jurnal dan 66 pengarang. Pada tahun 2010, Jurnal Kedokteran YARSI terbit sebanyak 16 artikel dan 37 pengarang. Tahun 2011,Jurnal Kedokteran YARSI tidak terbit sama sekali. Tahun 2012, Jurnal Kedokteran YARSI terbit sebanyak 18 artikel dan 47 pengarang. Tahun 2013, Jurnal Kedokteran YARSI terbit sebanyak 6 artikel dan 16 pengarang. Tahun 2014,Jurnal Kedokteran YARSI terbit sebanyak 6 artikel dan 11 pengarang. Tahun 2015, Jurnal Kedokteran YARSI terbit sebanyak 18 artikel dan 49 pengarang. Tahun 2016, Jurnal Kedokteran YARSI terbit sebanyak 17 artikel dan 25 pengarang. Tahun 2017, Jurnal Kedokteran YARSI terbit sebanyak 18 artikel dan 53 pengarang. Tahun 2018, Jurnal Kedokteran YARSI terbit sebanyak 18 artikel dan 51 pengarang. Total frekuensi terbit dari tahun 2009-2018 sebayak 143 artikel jurnal dan artikel jurnal dan 360 pengarang (lihat Gambar 4).

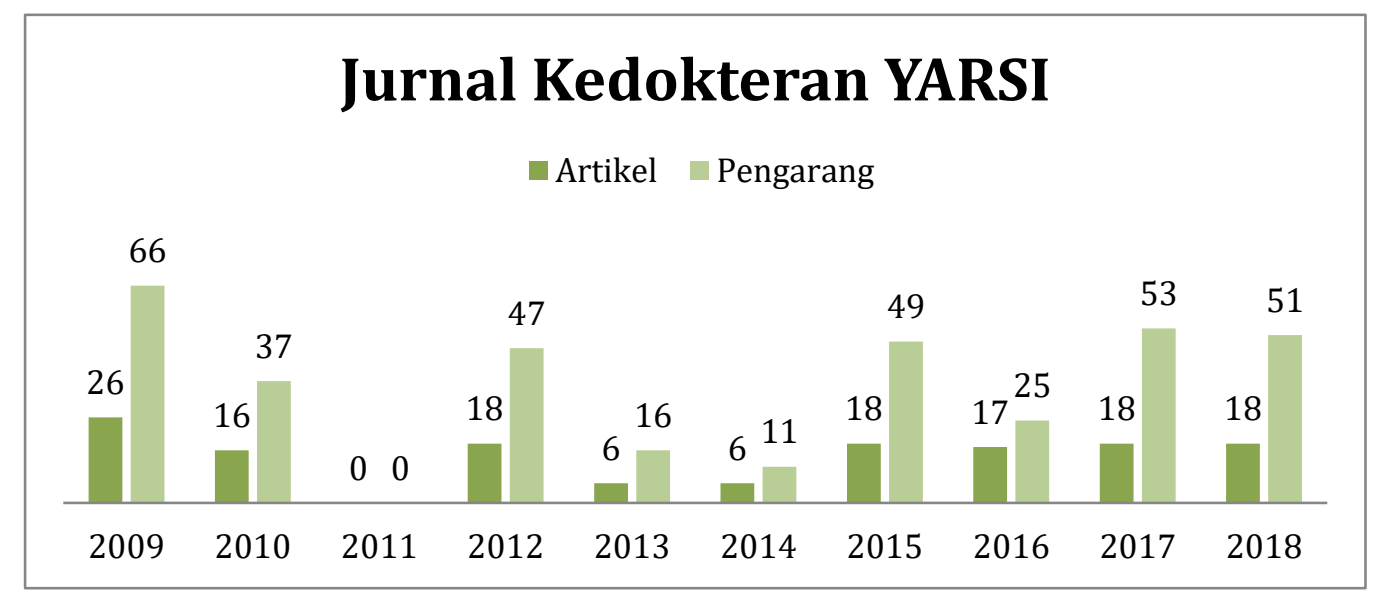

Gambar 4

Perkembangan jumlah artikel terbit dan pengarang pada Jurnal Kedokteran Yarsi periode tahun 2009-2018

\section{Perhitungan Parameter $\boldsymbol{n}$ dan $\mathrm{C}$}

Penelitian ini menggunakan teknik complete count yaitu teknik menghitung seluruh pengarang yang ada pada Jurnal Kedokteran YARSI. Terdapat 143 artikel jurnal dan 360 pengarang dalam rentangan tahun 2009-2018 pada Jurnal Kedokteran YARSI. Jumlah pengarang yang menghasilkan $n$ artikel di mana rentang jumlah artikel yang dihasilkan dalam 10 tahun terakhir adalah sebagai berikut: paling sedikit terdapat 215 pengarang yang berkontribusi sebanyak 1 artikel dalam rentang tahun 2009-2018 dan yang paling banyak terdapat 1 pengarang yang mampu berkontribusi hingga 8 artikel dalam rentang tahun 20092018 (lihat Tabel 3). Tabel 3 menunjukkan frekuensi artikel dan pengarang tahun 2009-2018. Perhitungan dilakukan dengan cara mengelompokan pengarang yang menghasilkan 1, 2 atau 3 sampai 8 artikel dalam rentangan tahun 2009-2018. Sebagai contoh sebanyak 210 
Tadwin:Jurnal Ilmu Perpustakaan dan Informasi,Vol 1 (1) 2020, Halaman: 1-12

Copyright @2020

Available Online at: http://jurnal.radenfatah.ac.id/index.php/tadwin

pengarang yang menulis 1 artikel, 32 pengarang yang menulis 2 artikel, 3 pengarang yang menuis 3 artikel dan seterusnya.

Tabel 3.

Rekapitulasi jumlah artikel dan jumlah pengarang tahun 2009-2018

\begin{tabular}{ccc} 
Jumlah Artikel & Jumlah Pengarang & $\boldsymbol{x} * \boldsymbol{y}$ \\
\hline 1 & 215 & 215 \\
2 & 32 & 64 \\
3 & 17 & 51 \\
4 & 1 & 4 \\
5 & 1 & 5 \\
6 & 1 & 6 \\
7 & 1 & 7 \\
8 & 1 & 8 \\
Jumlah & 269 & 360 \\
\hline
\end{tabular}

Tabel 3 selanjutnya dikembangkan menjadi 6 kolom (Lihat Tabel 4). Kolom pertama dan kedua berisi jumlah artikel $(x)$ dan jumlah pengarang $(y)$ dimana data-data tersebut disusun dari yang terkecil hingga yang terbesar. Kolom ketiga dan keempat adalah logaritma dari artikel $(x)$ dan pengarang $(y)$. Kolom kelima dan keenam dilambangkan dengan XY dengan keterangan perkalian $\log \mathrm{x}$ dan $\log \mathrm{y}$ dan $\mathrm{X}^{2}$ adalah hasil dari perkalian kuadrat $\log x$.

Tabel 4.

Perhitungan untuk Menduga Parmeter Hukum Lotka

\begin{tabular}{cccccc}
\hline Artikel (x) & Pengarang $(\mathbf{y})$ & $\mathbf{X}=\log \boldsymbol{x}$ & $\mathbf{Y}=\log \boldsymbol{y}$ & $\boldsymbol{X} \boldsymbol{~}$ & $\boldsymbol{X}^{\mathbf{2}}$ \\
\hline 1 & 215 & 0 & 2.33243846 & 0 & 0 \\
2 & 32 & 0.301029996 & 1.505149978 & 0.453095291 & 0.090619058 \\
3 & 17 & 0.477121255 & 1.230448921 & 0.587073333 & 0.227644692 \\
4 & 1 & 0.602059991 & 0 & 0 & 0.362476233 \\
5 & 1 & 0.698970004 & 0 & 0 & 0.488559067 \\
6 & 1 & 0.77815125 & 0 & 0 & 0.605519368 \\
7 & 1 & 0.84509804 & 0 & 0 & 0.714190697 \\
8 & 1 & 0.903089987 & 0 & 0 & 0.815571525 \\
Jumlah & 269 & 4.605520523 & 5.06803736 & 1.040168625 & 3.30458064 \\
\hline
\end{tabular}

Data pada kolom tersebut digunakan untuk mengetahui eksponen $n$ dan tetapan $\mathrm{C}$ atau konstanta. Untuk menghitung nilai-nilai peradugaan parameter Hukum Lotka, selanjutnya dimasukkan kedalam persamaan 1.1 adalah sebagai berikut:

$$
\begin{aligned}
b & =\frac{\Sigma X Y-N \overline{X Y}}{\Sigma x^{2}-N \bar{x}^{2}} \quad(\text { persamaan } 1.1) \\
b & =\frac{1.040168625-(8 \times 0.575690065 \times 0.63350467)}{3.30458064-\left(8 \times 0.575690065^{2}\right)} \\
b & =\frac{1.040168625-(8 \times 0.364702345)}{3.30458064-(8 \times 0.331419051)} \\
b & =\frac{1.040168625-2.917618759}{3.30458064-2.651352411} \\
b & =\frac{-1.877450134}{0.653228229}=-2.874110535
\end{aligned}
$$


Karena $\mathrm{b}=-n$ maka $n=-(-2.874110535)=2.874110535$

Diketahui nilai $n$ sebesar 2.874110535

\section{Distribusi Teoritis Hukum Lotka}

Nilai $n$ sebesar 2.874110535 memiliki arti bahwa eksponen untuk jumlah artikel adalah 2.874110535. Menurut Sulistyo-Basuki (1994) dalam Wahyudi (2015) untuk menentukan nilai $\mathrm{C}$ maka persamaan terbaik yang digunakan adalah dengan persamaan 1.2 berikut ini:

$$
\mathrm{C}=\frac{1}{\sum \frac{1}{\bar{x}^{n}}} \quad(\text { persamaan 1.2) }
$$

Jika diketahui $n=2.874110535$, sehingga diperoleh hasil sebagai berikut:

$$
\mathrm{C}=\frac{1}{\sum_{x^{n}}^{1}}
$$

Tabel 5

Perhitungan untuk menduga Parameter Hukum Lotka

\begin{tabular}{ccc} 
Artikel (x) & $\mathbf{X}^{\mathbf{n}}$ & $\mathbf{1}^{\mathbf{n}}$ \\
\hline 1 & 1 & 1 \\
2 & 7.331510854 & 0.136397534 \\
3 & 23.51252253 & 0.042530528 \\
4 & 53.75105141 & 0.018604287 \\
5 & 102.0744511 & 0.009796771 \\
6 & 172.3823141 & 0.005801059 \\
7 & 268.4758215 & 0.00372473 \\
8 & 394.0764168 & 0.002537579 \\
& $\Sigma 1 / \mathrm{X}^{\mathbf{n}}$ & 1.219392488 \\
\hline
\end{tabular}

$$
\begin{aligned}
& \mathrm{C}=\frac{1}{\sum \frac{1}{x^{n}}} \\
& \mathrm{C}=\frac{1}{\mathbf{1 . 2 1 9 3 9 2 4 8 8}}=0.820080499
\end{aligned}
$$

Berdasarkan perhitungan persamaan 1.2 tersebut diketahui nilai $\mathrm{C}=0.820080499$ dan nilai $n$ $=2.874110535$ maka dari perhitungan tersebut diperoleh persamaan pola produktivitas pengarang pada Jurnal Kedokteran YARSI tahun 2009-2018 adalah $Y x$. $X^{2.874110535}=$ 0.820080499 . Hal tersebut membuktikan bahwa banyaknya pengarang dengan kontribusi 1 artikel sekitar $82.00 \%$ dari total penulis yang memberikan kontribusi artikel pada Jurnal Kedokteran YARSI selama periode 10 tahun terakhir dari tahun 2009-2018.

\section{Distribusi Produktivitas Pengarang berdasarkan Hasil Pengamatan}

Pada tahun 1830 Lotka mengatakan bahwa penulis yang berkontribusi dalam satu artikel adalah $60 \%$ dari total penulis yang memberikan kontribusi. Itu berarti semakin banyak artikel yang ditulis semakin sedikit pengarangnya dan sebaliknya semakin banyak jumlah pengarang semakin sedikit jumlah artikel yang dihasilkan oleh pengarang. Berdasarkan hasil perhitungan data tersebut menghasilkan kontribusi 1 artikel sekitar $82.00 \%$ dapat dikatakan produktivitas Jurnal Kedokteran YARSI tahun 2009-2018 rendah atau kurang produktif. 
Penelitian sebelumnya yang dilakukan olehNurningsih tahun 2012melakukan Analisis Produktivitas Dosen Tetap Fakultas Kedokteran Universitas YARSI pada Jurnal Kedoktaran YARSI dengan Hukum Lotka. Penelitian yang dilakukan oleh Nurningsih hanya dibatasi pada pengarang atau dosen tetap yang berasal dari Universitas YARSI. Berdasarkan hasil penelitian yang dilakukan oleh Nurningsih diketahui banyaknya dosen yang memberikan kontribusi untuk 1 artikel adalah 63,72\% dari jumlah seluruh dosen artinya analisis yang dilakukan oleh Nurningsih tidak jauh berbeda dengan yang dikemukakan oleh Lotka.

Tabel 6 berikut ini merupakan hasil pengamatan dan pendugaan teoritis Hukum Lotka untuk melihat perbandingan hasil pengamatan dan pendugaan teoritis. Pada Tabel 6 terlihat perbedaan yang jelas pada persentase pengarang dengan kontribusi 3 artikel dengan selisih perdugaan $0.03 \%$ dengan jumlah pengarang sebanyak 17 pengarang. Jumlah pengarang terbanyak berdasarkan hasil pengamatan adalah 215 pengarang dengan kontriburi 1 artikel $79.92 \%$ sedangkan perdugaan jumlah pengarang adalah $82.00 \%$. Jumlah artikel terbanyak berdasarkan hasil pengamatan adalah 8 artikel yang merupakan kontribusi dari 1 orang pengarang yaitu $0.20 \%$, sedangkan pada perdugaan adalah $0.16 \%$.

Tabel 6.

Hasil pengamatan dan pedugaan Teoritis Hukum Lotka

\begin{tabular}{|c|c|c|c|c|c|c|}
\hline $\begin{array}{l}\text { Artikel } \\
(\mathbf{x})\end{array}$ & $\begin{array}{c}\text { Pengarang } \\
\text { (y) }\end{array}$ & $\begin{array}{c}\% \text { Pengarang } \\
\text { Hasil } \\
\text { Pengamatan } \\
\left(\mathbf{y} / \mathbf{\Sigma} \mathbf{y}^{*} \mathbf{1 0 0} \%\right)\end{array}$ & $\mathbf{X}^{\mathrm{n}}$ & C & $\begin{array}{c}\% \text { Pendugaan } \\
\text { Pengarang } \\
\text { Hukum Lotka } \\
\left(\mathrm{YX}=\mathrm{C} / \mathrm{X}^{\mathrm{n}}\right)\end{array}$ & Selisih \\
\hline 1 & 215 & 0.799256506 & 1 & 0.820080499 & 0.820080499 & -0.020823993 \\
\hline 2 & 32 & 0.118959108 & 7.331510854 & 0.820080499 & 0.111856958 & 0.00710215 \\
\hline 3 & 17 & 0.063197026 & 23.51252253 & 0.820080499 & 0.034878457 & 0.028318569 \\
\hline 4 & 1 & 0.003717472 & 53.75105141 & 0.820080499 & 0.015257013 & -0.011539541 \\
\hline 5 & 1 & 0.003717472 & 102.0744511 & 0.820080499 & 0.008034141 & -0.004316669 \\
\hline 6 & 1 & 0.003717472 & 172.3823141 & 0.820080499 & 0.004757335 & -0.001039863 \\
\hline 7 & 1 & 0.003717472 & 268.4758215 & 0.820080499 & 0.003054579 & 0.000662894 \\
\hline 8 & 1 & 0.003717472 & 394.0764168 & 0.820080499 & 0.002081019 & 0.001636453 \\
\hline Jumlah & 269 & 1 & & & 1 & \\
\hline
\end{tabular}

Pola Produktivitas Jurnal Kedokteran YARSI pada 10 tahun terakhir dari tahun 20092018 dapat dikatakan rendah atau kurang produktif. Berdasarkan hasil perhitungan disebabkan 1) pada tahun 2011 Jurnal Kedokteran YARSI tidak terbit; 2) artikel yang diterbitkan pada tahun 2013 dan tahun 2014 jumlahnya sedikit; 3) dari hasil perhitungan tersebut membuktikan tujuan pertama dari penelitian ini yaitu untuk mengetahui pola produktivitas pengarang menggunakan Hukum Lotka dengan teknik complete count pada Jurnal Kedokteran YARSI tahun 2009-2018.

\section{Uji Kolmogorov-Smirnov}

Uji Kolmogorov-Smirnov (Uji K-S) dilakukan terhadap persamaan nilai n dan C untuk menetapkan apakah hipotesis awal $H_{0}$ diterima atau ditolak. Coile (1977, p.10) menyarankan menggunakan tes Kolmogorov-Smirlov (K-S) untuk menguji kesesuaian Hukum Lotka pada data penelitian yang digunakan. Askew (2008) menambahkan para peneliti tes good-of-fit atau Kolmogorov-Smirnov menunjukkan bahwa pola produktivitas penulis mengikuti Hukum Lotka. Uji Kolmogorov-Smirnov (K-S) dilakukan seperti pada perhitungan Tabel 7. 
Tadwin:Jurnal Ilmu Perpustakaan dan Informasi,Vol 1 (1) 2020, Halaman: 1-12

Available Online at: http://jurnal.radenfatah.ac.id/index.php/tadwin

Tabel 7.

Uji Kolmogorov-Smirnov (K-S) pada Jurnal Kedokteran YARSI 2009-2018

\begin{tabular}{|c|c|c|c|c|c|c|c|}
\hline $\begin{array}{c}\text { Artikel } \\
(x)\end{array}$ & $\begin{array}{c}\text { Penulis } \\
(y)\end{array}$ & $\begin{array}{c}\text { Persentase } \\
\text { Jumlah } \\
\text { Pengarang } \\
(y) \\
\end{array}$ & $\begin{array}{c}\text { Jumlah } \\
\text { Komulatif } \\
\text { Persentase } \\
y[S n(x)] \\
\end{array}$ & $\begin{array}{c}\text { Frekuensi } \\
\text { Teoritis } \\
\text { Hukum } \\
\text { Lotka }[Y x] \\
\end{array}$ & $\begin{array}{l}\text { Persentase } \\
\text { Jumlah } \\
\text { Frekuensi } \\
\text { Teoritis } \\
\text { Hukum } \\
\text { Lotka }(Y x) \\
\end{array}$ & $\begin{array}{c}\text { Jumlah } \\
\text { Komulatif } \\
\text { Frekuensi } \\
\text { Teoritis [F0 } \\
(x)]\end{array}$ & $\begin{array}{l}\mid \mathrm{F} 0(\mathrm{X})- \\
\mathrm{Sn}(\mathrm{X})]\end{array}$ \\
\hline 1 & 215 & 0.799256506 & 0.7992565 & 0.820080499 & 0.820080498 & 0.765100577 & -0.0341559 \\
\hline 2 & 32 & 0.118959108 & 0.9182156 & 0.111856958 & 0.111856958 & 0.876957535 & -0.0412581 \\
\hline 3 & 17 & 0.063197026 & 0.9814126 & 0.034878457 & 0.034878457 & 0.911835992 & -0.0695766 \\
\hline 4 & 1 & 0.003717472 & 0.9851301 & 0.015257013 & 0.015257013 & 0.927093005 & -0.0580371 \\
\hline 5 & 1 & 0.003717472 & 0.9888476 & 0.008034141 & 0.008034141 & 0.935127146 & -0.0537204 \\
\hline 6 & 1 & 0.003717472 & 0.9925651 & 0.004757335 & 0.004757335 & 0.939884481 & -0.0526806 \\
\hline 7 & 1 & 0.003717472 & 0.9962825 & 0.003054579 & 0.003054579 & 0.94293906 & -0.0533435 \\
\hline \multirow[t]{2}{*}{8} & 1 & 0.003717472 & 1 & 0.002081019 & 0.002081019 & 0.945020079 & 0 \\
\hline & 269 & 1 & & 1.000000001 & 1 & 7.243957875 & \\
\hline
\end{tabular}

Berdasarkan Tabel 7 diketahui nilai deviasi maksimum (Dmaks) adalah 0. Uji Kolmogorov-Smirnov (Uji K-S) menggunakan nilai kritis pada taraf nyata 5\% $(\alpha=0,05)$ artinya kesalahan data adalah 5\% dan tingkat kepercayaan data adalah 95\%. Jumlah pengarang (N) pada Jurnal Kedokteran YARSI tahun 2009-2018 sebanyak 269 orang pengarang sehingga dapat dicari menggunakan persamaan $\frac{1,36}{\sqrt{N}}$. Perhitungannya adalah sebagai berikut:

Nilai kritis Uji Kolmogorov-Smirnov (Uji K-S) untuk $\alpha=0,05=\frac{1,36}{269}=0.0829206$.

Dari hasil perhitungan di atas diketahui $\mathrm{D}_{\text {maks }}=0<\mathrm{K}-\mathrm{S}=0.0829206$ artinya Dmaks lebih kecil daripada nilai kritis dapat diartikan bahwa tidak ada perbedaan yang signifikan antara rumus Hukum Lotka dengan hasil pengamatan. Hal tersebut menunjukan hipotesis awal $H_{0}$ diterima $H_{1}$ ditolak maka pola produktivitas pengarang menggunakan teknik complete count pada Jurnal Kedokteran YARSI tahun 2009-2018 sesuai dengan Hukum Lotka. Perhitungan tersebut membuktikan tujuan kedua dari penelitian ini yaitu untuk menguji kesesuaian frekuensi Hukum Lotka dengan distribusi frekuensi pengarang menggunakan teknik complete count pada Jurnal Kedokteran YARSI tahun 2009-2018. Hal tersebut sesuai dengan Uji K-S yang dilakukan oleh Nurningsih 2012 yang menunjukkan nilai kritis adalah 0,2206 dan deviasi maksimum adalah 0,0628 artinya tidak ada perbedaan yang signifikan antara rumus Lotka dengan hasil pengamatan.

\section{Produktivitas Pengarang Jurnal Kedokteran Yarsi}

Berdasarkan data perhitungan yang telah dilakukan pada Jurnal Kedokteran YARSIpada tahun2009-2018 terdapat 143 artikel dengan 360 pengarang. Pengarang yang produktif dalam penelitian tersebut adalah pegarang yang memberikan kontribusi artikel paling banyak dari tahun yang ditentukan. Tabel 8 menunjukkan beberapa pengarang padaJurnal Kedokteran YARSI yang paling produktif selama 10 tahun terakhir dengan kontribusi minimal 3 artikel. 
Berdasarkan Tabel 8 diketahui bahwa pengarang yang paling produktif berasal dari internal Universitas YARSI, yaitu Endang Purwaningsih yang merupakan dosen Fakultas Kedokteran Universitas YARSI. Endang Purwaningsih berkontribusi pada Jurnal Kedokteran YARSI sebanyak 8 artikel dalam 10 tahun terakhir sejak tahun 2009-2018.Berikutnya ada Artha Budi Susila Duarsa dari Fakultas Kedokteran Universitas YARSI yang berkonstribusi sebanyak 7 artikel pada Jurnal Kedokteran YARSI dari tahun 2009-2018. Selanjutnya adalah Erlina Wijayanti dari Fakultas Kedokteran Universitas YARSI yang berkonstribusi sebanyak 6 artikel pada Jurnal Kedokteran YARSI dari tahun 2009-2018. Setelah itu ada Anna Priangani Roswiem dari Halal Research Center, Universitas YARSI yang berkonstribusi sebanyak 5 artikel selama 10 tahun dari tahun 2009-2018. Pengarang produktif selanjutnya adalah Endang Sutisna dari Universitas Sebelas Maret (UNS) yang berkonstribusi sebanyak 4 artikel selama 10 tahun dari tahun 2009-2018.

Tabel 8

Produktifitas pengarang Jurnal Kedokteran YARSI tahun 2009-2018

\begin{tabular}{|c|c|c|c|c|}
\hline No & Nama & Intitusi & Gender & $\begin{array}{l}\text { Jumlah } \\
\text { Artikel } \\
\end{array}$ \\
\hline 1 & Endang Purwaningsih & Universitas YARSI & Perempuan & 8 \\
\hline 2 & Artha Budi Susila Duarsa & Universitas YARSI & Laki-laki & 7 \\
\hline 3 & Erlina Wijayanti & Universitas YARSI & Perempuan & 6 \\
\hline 4 & Anna Priangani Roswiem & Universitas YARSI & Perempuan & 5 \\
\hline 5 & Endang Sutisna & $\begin{array}{c}\text { Universitas Sebelas Maret } \\
\text { (UNS) }\end{array}$ & Perempuan & 4 \\
\hline 6 & Rika Yuliwulandari & Universitas YARSI & Perempuan & 3 \\
\hline 7 & Kholis Ernawati & Universitas YARSI & Perempuan & 3 \\
\hline 8 & Hasan Boesri & $\begin{array}{l}\text { Vector and Reservoir } \\
\text { Disease Research and } \\
\text { Development Institute } \\
\text { (VRDRDI), Salatiga }\end{array}$ & Laki-laki & 3 \\
\hline 9 & Fatimawali Umar & $\begin{array}{c}\text { Universitas Sam } \\
\text { Ratulangi }\end{array}$ & Perempuan & 3 \\
\hline 10 & Indra Kusuma & Universitas Indonesia & Laki-laki & 3 \\
\hline 11 & Muhammad Ardiansyah & $\begin{array}{c}\text { Universitas } \\
\text { Muhammadiyah Jakarta }\end{array}$ & Laki-laki & 3 \\
\hline 12 & H. Ardiyan Boer & Universitas Trisakti & Laki-laki & 3 \\
\hline 13 & Zinatul Hayati & Universitas Syiah Kuala & Perempuan & 3 \\
\hline 14 & Bhisma Murti & $\begin{array}{c}\text { Universitas Sebelas Maret } \\
\text { (UNS) }\end{array}$ & Laki-laki & 3 \\
\hline 15 & Sutji Pratiwi Rahardjo & Universitas Hasanuddin & Laki-laki & 3 \\
\hline 16 & Riskiana Djamin & Universitas Hasanuddin & Perempuan & 3 \\
\hline 17 & Billy J. Kepel & Universitas Hasanuddin & Laki-laki & 3 \\
\hline 18 & $\begin{array}{l}\text { Sidhi Laksono } \\
\text { Purwowiyoto }\end{array}$ & Universitas YARSI & Laki-laki & 3 \\
\hline 19 & Susi Endrini & Universitas YARSI & Perempuan & 3 \\
\hline 20 & Titiek Djannatun & Universitas YARSI & Perempuan & 3 \\
\hline 21 & Tri Susmiarsih Panjiasih & Universitas YARSI & Perempuan & 3 \\
\hline 22 & Samsul Mustofa & Universitas YARSI & Laki-laki & 3 \\
\hline
\end{tabular}


Tadwin:Jurnal Ilmu Perpustakaan dan Informasi,Vol 1 (1) 2020, Halaman: 1-12

Copyright $@ 2020$

Available Online at: http://jurnal.radenfatah.ac.id/index.php/tadwin

\section{SIMPULAN}

Pola Produktivitas Pengarang menggunaan Hukum Lotka pada Jurnal Kedokteran YARSI Tahun 2009-2018 dengan nilai eksponen (n) 2.874110535 dan tetapan (C) 0.820080499. Hal ini berarti pengarang yang berkontribusi untuk satu artikel adalah $82.00 \%$ dari total jumlah pengarang. Dengan demikian dapat dikatakan bahwa pola produktivitas Jurnal Kedokteran YARSI menggunakan Teknik Complete Count tahun 2009-2018 rendah atau kurang produktif. Berdasarkan hasil uji Kolmogorov-Smirnov menunjukan kesesuaian frekuensi Hukum Lotka dengan distribusi frekuensi pengarang. Ini artinya tidak ada perbedaan yang signifikan antara rumus Hukum Lotka dengan hasil pengamatan.

\section{DAFTAR PUSTAKA}

Askew, C. A. (2008). An Examination of Lotka's law in the Field of Library and Information Studies (Florida International University). https://doi.org/10.25148/etd.FI10022502

C.Coile, R. (1977). Lotka's Frequency Distribution of Scentific Productivity. Journal of the American Socienty for Information Science, 28(6), 1-16. Retrieved from https://apps.dtic.mil/dtic/tr/fulltext/u2/a054425.pdf

Endang, F. (2012). Pengantar Kajian Bibliometrika dalam Perspektif Pustakawan. Jurnal Ilmiah Kepustakawanan "Libraria,"2(1), 1-17. Retrieved from https://repository.ipb.ac.id/handle/123456789/78764

Lasa Hs, U. S. (2017). Kamus Kepustakawanan Indonesia (4th ed.). Yogyakarta: Calpulis.

Martono, N. (2016). Metode Penelitian Kunatitatif: Analisis Isi dan Analisis Data Sekunder. Jakarta: Raja Grafindo Persada.

Nelisa, M. (2009). Produktivitas Pengarang Artikel Bidang Ilmu Perpustakaan dan Informasi di Indonesia Tahun 1978-2007: Analisis Bbibliometrika Menggunakan Hukum Lotka. Universitas Indonesia, Depok.

Nurningsih, S. (2012). Analisis Produktivitas Dosen tetap Fakultas Kedokteran Univeristas YARSI pada Jurnal Kedokteran YARSI. In Institut Pertanian Bogor.

Riduwan. (2014). Metode dan Teknik Penyusunan Tesis. Bandung: Alfabeta.

Tsay, M. (2004). Literature growth, journal characteristics, and author productivity in subject indexing, 1977 to 2000. Journal of the American Society for Information Science and $\begin{array}{lllll}\text { Technology, } & 55(1), & \text { 64-73. } & \text { Retrieved }\end{array}$ https://onlinelibrary.wiley.com/doi/abs/10.1002/asi.10346

Tupan. (2016). Pemanfaatan Repositori Institusi menuju Open Access : Studi Bibliometrik. Khizanah Al-Hikmah, 2(August). 
Tadwin:Jurnal Ilmu Perpustakaan dan Informasi,Vol 1 (1) 2020, Halaman: 1-12

Copyright $@ 2020$

Available Online at: http://jurnal.radenfatah.ac.id/index.php/tadwin

Wahyudi, A. (2015). Analisis Pola Produktivitas Penulis Artikel Bidang Perpustakaan Dan Informasi Di Indonesia: Suatu Kajian Bibliometrika. Retrieved from https://repository.ipb.ac.id/handle/123456789/78764

Wulan, S. (2014). Produktivitas dan Tingkat Kolaborasi Penulias dalam Karya Ilmiah Peneliti Bidang Zoologi, Puslit Biologi-LIPI 2005-2010. VisipustakA : Jaringan Infoermasi Antar Pustakawan, 16(2), 176-184. 